\title{
Relationship between expression of Livin and the biological behavior of human oral squamous cell carcinoma
}

\author{
DONG HOON LEE ${ }^{1}$, TAE MI YOON ${ }^{1}$, SUN-AE KIM $^{1}$, YOUNG-LAN PARK $^{2}$, KYUNG-HWA LEE $^{3}$, \\ SANG CHUL LIM ${ }^{1}$, JOON KYOO LEE ${ }^{1}$ and YOUNG EUN JOO ${ }^{2}$ \\ Departments of ${ }^{1}$ Otorhinolaryngology - Head and Neck Surgery, ${ }^{2}$ Internal Medicine, and ${ }^{3}$ Pathology, \\ Chonnam National University Medical School, Research Institute of Medical Sciences, \\ Chonnam National University and Hwasun Hospital, Hwasun 519-809, Republic of Korea
}

Received June 2, 2014; Accepted August 28, 2014

DOI: $10.3892 /$ or.2014.3510

\begin{abstract}
Livin is one of the most important members of the inhibitor protein (IAP) family. It is overexpressed in several types of tumors and may have prognostic significance. The purpose of this study was to investigate Livin expression in human oral squamous cell carcinomas (OSCCs) and to determine whether Livin affects tumor cell behavior in OSCC cell lines and thus evaluate its potential usefulness in serving as a possible target for molecular-targeted therapy in a preclinical model. The expression of Livin protein was investigated in human OSCC tissues through immunohistochemistry and western blot analysis. To evaluate the impact of Livin knockdown on the behavior of human OSCC cell lines, invasion, migration, proliferation and apoptosis assays using small-interfering RNA (siRNA) were performed. RT-PCR and western blot analysis were used to assess alteration of Livin expression at the mRNA and protein levels. The results revealed that expression of Livin was increased in the human OSCC tissues compared with the adjacent normal mucosa. In addition, immunoreactivity of Livin was expressed in 8 OSCC tissues (44.4\%). Knockdown of Livin resulted in significantly reduced cell invasion, migration and proliferation in the human OSCC cells. Livin knockdown induced cell apoptosis in the human OSCC cells. Moreover, Livin inhibited apoptosis by suppressing the activity of caspases in the human OSCC cells. In conclusion, livin is associated with invasive and oncogenic phenotypes such as tumor cell invasion, tumor cell migration, tumor cell proliferation, and resistance to apoptosis in human OSCC cells.
\end{abstract}

Correspondence to: Professor Young Eun Joo, Department of Internal Medicine, Chonnam National University Medical School, Hwasun Hospital, 160 Ilsim-ri, Hwasun-eup, Hwasun 519-809, Republic of Korea

E-mail: yejoo@chonnam.ac.kr

Key words: Livin protein, oral cancer, squamous cell carcinoma, disease progression, molecular-targeted therapy

\section{Introduction}

Head and neck cancer refers to a group of biologically similar cancers that start in the lip, oral cavity, nasal cavity, paranasal sinuses, pharynx and larynx. Ninety percent of head and neck cancers are squamous cell carcinomas, originating from the epithelium of these regions. Head and neck squamous cell carcinomas (HNSCCs) represent approximately $2.4 \%$ of all cancers diagnosed and were implicated in 7,600 deaths in 2009 (1). Although early-stage head and neck cancers, particularly laryngeal and oral cavity cancers, have high cure rates, up to $50 \%$ of head and neck cancer patients present with advanced disease (2). The patients with locally advanced disease have a 5-year survival rate of approximately 50\%, and $10 \%$ of patients who suffer from distant metastatic disease have a 5-year survival rate of approximately $25 \%$ (3). Despite the advancement achieved in surgical methods and radiation therapy, the prognosis of head and neck cancers has not shown a satisfactory improvement (1-6). Therefore, in order to achieve more effective treatment of patients with HNSCC, particularly patients with advanced disease, new treatment modalities such as molecular-targeted therapy are clearly needed.

The family of inhibitor of apoptosis protein (IAP) consists of a group of structurally related proteins with anti-apoptotic properties $(7,8)$. Currently, eight human IAP members have been identified, including cIAP1, cIAP2, NAIP, Survivin, XIAP, BRUCE, ILP-2 and Livin (9-14). Livin is a novel member of the IAP family. In contrast to other members of the IAP family, such as cIAP1, cIAP2, XIAP and NIAP, it is expressed at low levels in normal adult tissues, but is overexpressed in a wide variety of human malignancies, such as colon cancer, leukemia, bladder cancer, neuroblastoma. malignant pleural methothelioma, pancreatic cancer, osteosarcoma, renal cell carcinoma, gastric cancer, breast carcinoma and lung cancer (15-29). It has been reported that Livin may be involved in the progression of tumors, and high levels of this molecule are correlated with tumor progression and patient outcome $(22,30)$. However, the impact and expression of Livin in the progression of HNSCC are still unknown, and this issue has not been reported in any studies, except Livin in nasopharyngeal carcinoma (32). 
In order to analyze the pathobiological significance of Livin in human oral squamous cell carcinomas (OSCCs), we examined expression of Livin and investigated the potential relevance between its expression and various clinicopathological variables in a well-defined series of OSCCs. We also determine whether Livin affects tumor cell invasion, migration, proliferation and apoptosis in OSCC cell lines. This study demonstrated Livin expression and its association with tumor progression in OSCC and may provide the basis for applying Livin in the molecular-targeted therapy for OSCCs.

\section{Materials and methods}

Patients and tumor specimens. To evaluate Livin protein expression, paraffin-embedded tissue sections were collected from 18 patients who underwent definitive surgery for OSCC at Chonnam National University Hwasun Hospital (Jeonnam, Korea) between March 2006 and August 2009. All 18 patients underwent appropriate definitive surgery. In 6 patients, surgery was followed by radiation therapy alone or cisplatin-based concurrent chemoradiation therapy.

Patient characteristics including age, gender, tumor location, stage, depth of tumor invasion, lymph node metastasis, distant metastasis, treatment, recurrence, survival and followup information were obtained by review of the hospital records. All patients were staged according to the 7th edition of the American Joint Committee on Cancer (AJCC) staging system (33). Overall survival was calculated from the first surgical date to the date of death or the date of last follow-up.

Immunohistochemistry. Livin protein expression was investigated immunohistochemically in formalin-fixed, paraffin-embedded tissue blocks obtained from 18 OSCC patients. Tissue sections $(5 \mu \mathrm{m})$ were cut from each paraffin block, mounted, and dried on glass slides. Tissues were deparaffinized, rehydrated, and retrieved with retrieval buffer. Endogenous peroxidase activity was blocked with peroxidaseblocking solution (Dako, Carpinteria, CA, USA), followed by incubation with polyclonal rabbit anti-human Livin (Santa Cruz Biotechnology, Santa Cruz, CA, USA) overnight at $4^{\circ} \mathrm{C}$. After washing in Tris-buffered saline-Tween-20 buffer (TBST), tissues were stained using the Dako Real ${ }^{\mathrm{TM}}$ Envision horseradish peroxidase (HRP)/3,3'-diaminobenzidine (DAB) detection system (Dako). Tissues were counterstained with hematoxylin and mounted with coverslips. Stained tissues were viewed and photographed using a light microscope. Assessment of staining was interpreted by two independent observers who were without knowledge regarding the clinical information. The percentage of positive immunostaining cells was graded according to three levels: $0,<5 \% ; 1,5-50 \%$; and $2, \geq 50 \%$.

Cell culture and transfection. Cells of the human OSCC cell line, PCI 50, were cultured in RPMI-1640 (Invitrogen, Carlsbad, CA, USA) supplemented with $10 \%$ fetal bovine serum (Hyclone, Logan, UT, USA), $50 \mathrm{U} / \mathrm{ml}$ penicillin, and $50 \mu \mathrm{g} / \mathrm{ml}$ streptomycin (Gibco, Grand Island, NY, USA) in a humidified atmosphere of $5 \% \mathrm{CO}_{2}$ at $37^{\circ} \mathrm{C}$. The PCI 50 cell line originated from oral cavity cancer. For transfection, cells were prepared and maintained in culture dishes with medium, and cells were seeded on 6-well plates at $2 \times 10^{5}$ cells per well at the time of transfection. To study the biological role of Livin in OSCC, small interfering RNA (siRNA) was used to knock down endogenous Livin gene expression in the PCI 50 cells. Cells were transfected with Livin-specific siRNA (Bioneer, Daejeon, Korea) and negative control siRNA (Qiagen, Valencia, CA, USA) using Lipofectamine ${ }^{\mathrm{TM}} 2000$ (Invitrogen). Forty eight hours after transfection, the viable transfected cells were enumerated and re-seeded in the individual experimental apparatus.

Cell invasion assay. Cell invasion was measured using a Transwell invasion apparatus (Costar, Cambridge, UK). Transwell filters $(8.0-\mu \mathrm{m}$ pore size) were coated overnight with $1 \%$ gelatin solution on both the top and bottom surfaces and dried at room temperature. Cells transfected with Livin siRNA or negative control siRNA were seeded at $3 \times 10^{5}$ cells in $120 \mu \mathrm{l}$ of a $0.2 \%$ bovine serum albumin (BSA) suspension in the upper chamber. Subsequently, $400 \mu 1$ of $0.2 \%$ BSA containing $7 \mu \mathrm{g} / \mathrm{ml}$ fibronectin (Calbiochem, La Jolla, CA, USA) as the chemoattractant was loaded into the lower chamber. After incubation for $24 \mathrm{~h}$, cells on the top surface of the filter were wiped off with cottonballs. Cells that had migrated to the bottom surface of the Transwell were stained with Diff Quik solution (Sysmex, Kobe, Japan) and counted in five random squares in the microscopic field of view. Results are expressed as the mean \pm standard error of the number of cells/field in three individual experiments.

Cell migration assay (wound healing assay). Cells transfected with Livin siRNA or negative control siRNA were seeded in each well of Culture-Inserts ${ }^{\circledR}$ (Ibidi, Bonn, Germany) at $1.5 \times 10^{5}$ cells/well. After incubation for $24 \mathrm{~h}$, each insert was detached and the progression of cell migration was ascertained by photography at $0,8,12$ and $24 \mathrm{~h}$ using an inverted microscope. The distance between gaps was normalized to $1 \mathrm{~cm}$ after capture of three random sites.

Cell viability. Cell viability was determined with the EZ-CyTox (tetrazolium salt, WST-1) cell viability assay kit (Daeil Lab Inc., Seoul, Korea). After applying the WST-1 reagent at $37^{\circ} \mathrm{C}$, cell viability was measured using a microplate reader (Infinite M200; Tecan, Austria GmbH, Vienna, Austria) with Magellan V6 data analysis software (Tecan). Triplicate wells were used for each experiment, and all experiments were conducted at least in triplicate.

Cell apoptosis assay. Apoptosis was determined by Annexin V-fluorescein isothiocyanate (FITC) assay. Cells transfected with Livin siRNA or negative control siRNA were collected using trypsin, washed twice in phosphate-buffered saline (PBS) twice and re-suspended in binding buffer (BD Biosciences ${ }^{\circledast}$, San Diego, CA, USA). Annexin V-FITC and 7-amino-actinomycin D (7-AAD; BD Biosciences) were added to the cells, which were then incubated in the dark for $15 \mathrm{~min}$, then added and re-suspended in $400 \mathrm{ml}$ of binding buffer. Cells were analyzed using a FACSCalibur flow cytometer (Becton Dickinson, San Jose, CA). Data analysis was performed using standard Cell Quest software (Becton Dickinson). 

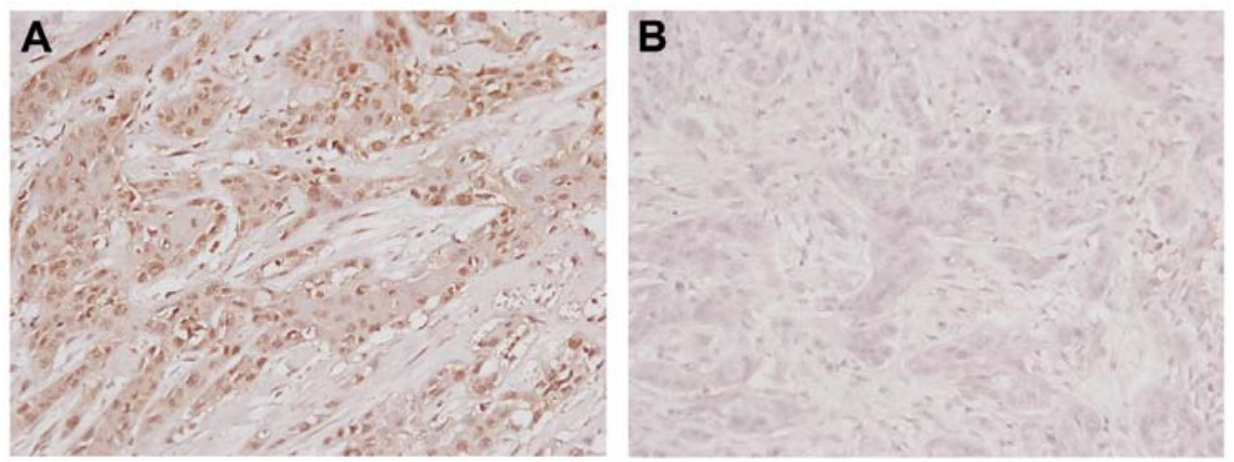

Figure 1. Immunohistochemical staining of Livin in human oral squamous cell carcinoma (OSCC) tissues. (A) Human OSCC tissue showing 2+ strong nuclear Livin immunolabeling. Magnification x200. (B) Human OSCC tissue showing no Livin immunoreactivity as a negative control. Magnification x200.

Protein isolation and western blot analysis. Cells and tissues were lysed in RIPA buffer (1 M Tris-HCl, $150 \mathrm{mM} \mathrm{NaCl}, 1 \%$ Triton X-100, 2 mMEDTA) with $1 \mathrm{mM}$ phenylmethanesulfonyl fluoride (PMSF), Halt ${ }^{\mathrm{TM}}$ phosphatase inhibitor and Halt ${ }^{\mathrm{TM}}$ protease inhibitor cocktail (Thermo, Rockford, IL, USA). Resolved proteins (10-20 $\mu \mathrm{g}$ ) were subjected to sodium dodecyl sulfate-polyacrylamide gel electrophoresis (SDS-PAGE), and the resolved proteins were electrophoretically transferred to polyvinylidene fluoride (PVDF) membranes (Millipore, Billerica, MA, USA). After blocking with 5\% BSA in TBST at room temperature for $1 \mathrm{~h}$, the PVDF membranes were sequentially blotted with the primary antibodies: polyclonal anti-human Livin, cleaved caspase-3, cleaved caspase-7, cleaved poly-ADP ribose polymerase (PARP) and $\beta$-actin (Santa Cruz Biotechnology, Santa Cruz, CA, USA) and polyclonal anti-human glyceraldehyde 3-phosphate dehydrogenase (GAPDH; Santa Cruz Biotechnology) at $4^{\circ} \mathrm{C}$ overnight. After rinsing in TBST, each membrane was incubated with the anti-rabbit or anti-mouse HRP-conjugated secondary antibody (Santa Cruz Biotechnology) at room temperature for $1 \mathrm{~h}$. Blots were detected with chemiluminescence (ECL) HRP substrate (Millipore) and recorded by a Ras-4000 image reader (Fujifilm, Tokyo, Japan).

$R N A$ isolation and reverse transcriptase-polymerase chain reaction ( $R T-P C R)$. The RNA from cells was isolated using TRIzol reagent (Invitrogen), reverse transcribed, and amplified using specific primers for Livin and GAPDH. Primer sequences were: Livin 5'-CACACAGGCCATCAGGAC AAG-3'/5'-ACGGCACAAAGACGATGGAC-3' and GAPDH 5'-ACCACAGTCCATGCCATCAC-3'/5'-TCCACCACCCTG TTGCTGTA-3'. The size of the amplified products was $456 \mathrm{bp}$ for Livin $\alpha$ and 403 bp for Livin $\beta$. For cDNA synthesis, $1 \mu \mathrm{g}$ of mRNA was mixed with $50 \mathrm{ng} / \mu \mathrm{l}$ oligo-dT (Promega, Madison, WI, USA), MMLV reverse transcriptase (Invitrogen) and RNAsin (Takara Bio, Shiga, Japan) and incubation was continued at $42^{\circ} \mathrm{C}$ for $1 \mathrm{~h}$ and at $72^{\circ} \mathrm{C}$ for $15 \mathrm{~min}$. PCR amplification of cDNA was performed using specific primers and GoTaq $^{\circledR}$ DNA polymerase (Promega). PCR products were separated by electrophoresis on a $1 \%$ agarose gel containing ethidium bromide.

Statistical analysis. Experimental differences between the Livin knockdown group and the control group were tested with the Student's t-test. The statistical software program SigmaPlot Software (version 6.0; Systat Software, San Jose, CA, USA) was used. Survival curves were calculated using the Kaplan-Meier method, and comparison of the curves was performed using the log-rank test. The statistical software program used was Statistical Package for the Social Sciences (SPSS) version 18.0 (Microcal Software Inc., Chicago, IL, USA) was used. A p-value $<0.05$ was considered to indicate a statistically significant result.

\section{Results}

Expression of Livin is increased in the OSCC tissues compared with normal mucosa. The patient data are summarized in Table I. The study group of patients included 12 males and 6 females. The mean age was $59.8 \pm 10.8$ years (mean \pm standard deviation), with a range from 41 to 79 years. The mean follow-up period was 50.5 months, with a range from 11.2 to 84.7 months. Immunohistochemical analysis revealed that 8 (44.4\%) of the 18 OSCC tissues overexpressed Livin relative to the adjacent normal mucosa. A pattern of strong nuclear staining was evident (Fig. 1A). In contrast, there was no staining in another OSCC tissue sample as negative control (Fig. 1B). The number of positive tumor cells for each tissue was recorded. Three tissues $(16.7 \%)$ showed $2+$ staining and five tissues $(27.8 \%)$ had $1+$ staining. Ten tissues $(55.6 \%)$ had negative staining.

Correlations between Livin protein expression and clinicopathological characteristics of the human OSCC cases. Correlations between Livin protein expression and clinicopathological characteristics in human OSCC are shown in Table II. Livin protein expression was not associated with age, gender, tumor location, stage, $\mathrm{T}$ stage, $\mathrm{N}$ stage, distant metastasis and recurrence $(\mathrm{p}>0.05)$ (Table II).

For the 18 patients with OSCC enrolled in this study, the 3-year overall survival rate was $72 \%$. The 3 -year overall survival was $80 \%$ in the negative Livin group, and $63 \%$ in the positive Livin group. Livin expression was not associated with patient overall survival ( $\mathrm{p}=0.54)$ (Fig. 2).

Knockdown of Livin suppresses tumor cell invasion, migration and proliferation in human OSCC cells

Expression and knockdown of Livin in a human OSCC cell 
Table I. Clinicopathological features of the 18 patients with oral squamous cell carcinoma.

\begin{tabular}{|c|c|}
\hline Clinicopathological features & Data \\
\hline \multicolumn{2}{|l|}{ Age (years) } \\
\hline Mean \pm SD & $59.8 \pm 10.8$ \\
\hline Range & 41-79 \\
\hline \multicolumn{2}{|l|}{ Gender, $\mathrm{n}$} \\
\hline Male & 12 \\
\hline Female & 6 \\
\hline \multicolumn{2}{|l|}{ Location, $\mathrm{n}$} \\
\hline FOM & 4 \\
\hline Oral tongue & 13 \\
\hline Buccal mucosa & 1 \\
\hline \multicolumn{2}{|l|}{ Stage, $\mathrm{n}$} \\
\hline I & 9 \\
\hline II & 4 \\
\hline III & 3 \\
\hline IV & 2 \\
\hline \multicolumn{2}{|l|}{ T stage, $\mathrm{n}$} \\
\hline $\mathrm{T} 1$ & 9 \\
\hline $\mathrm{T} 2$ & 7 \\
\hline $\mathrm{T} 3$ & 2 \\
\hline \multicolumn{2}{|l|}{$\mathrm{N}$ stage, $\mathrm{n}$} \\
\hline No & 13 \\
\hline N1 & 3 \\
\hline $\mathrm{N} 2$ & 2 \\
\hline \multicolumn{2}{|l|}{ Distant metastasis, $\mathrm{n}$} \\
\hline M0 & 17 \\
\hline M1 & 1 \\
\hline \multicolumn{2}{|l|}{ Recurrence, $\mathrm{n}$} \\
\hline Negative & 13 \\
\hline Positive & 5 \\
\hline 3-year overall survival (\%) & 72 \\
\hline \multicolumn{2}{|l|}{ Livin expression, $\mathrm{n}(\%)$} \\
\hline Negative & $10(55.6 \%)$ \\
\hline Positive & $8(44.4 \%)$ \\
\hline
\end{tabular}

SD, standard deviation; FOM, floor of mouth.

line. RT-PCR analysis demonstrated Livin mRNA expression in the OSCC cell line (Fig. 3A). Western blot analysis confirmed high Livin expression in the PCI 50 cells (Fig. 3B).

Knockdown of Livin results in significantly reduced cell invasiveness in human OSCC cells. In the cell invasion assay, the number of invasive Livin siRNA-transfected PCI 50 cells was $1029.0 \pm 28.7$, whereas the number of invasive cells in the negative control siRNA-transfected PCI 50 cells was 511.0 \pm 24.1 . The difference between the two groups was statistically significant $(p<0.01)$ (Fig. 4). Livin knockdown resulted in significantly reduced cell invasiveness in the human OSCC cells.

Knockdown of Livin results in significantly diminished cell migration in human OSCC cells. In the cell migration assay,
Table II. Correlation between Livin expression and the clinicopathological features of the patients with oral squamous cell carcinoma.

\begin{tabular}{|c|c|c|c|}
\hline \multirow[b]{2}{*}{ Features } & \multicolumn{2}{|c|}{ Livin expression } & \multirow[b]{2}{*}{ P-value } \\
\hline & $\begin{array}{c}\text { Negative } \\
(n=10)\end{array}$ & $\begin{array}{l}\text { Positive } \\
\quad(n=8)\end{array}$ & \\
\hline Age (years) & & & 0.19 \\
\hline$<60$ & 6 & 2 & \\
\hline$\geq 60$ & 4 & 6 & \\
\hline Gender & & & 0.32 \\
\hline Male & 8 & 4 & \\
\hline Female & 2 & 4 & \\
\hline Location & & & 1.00 \\
\hline FOM, buccal mucosa & 3 & 2 & \\
\hline Oral tongue & 7 & 6 & \\
\hline Stage & & & 0.61 \\
\hline I, II & 8 & 5 & \\
\hline III, IV & 2 & 3 & \\
\hline T stage & & & 1.00 \\
\hline $\mathrm{T} 1$ & 5 & 4 & \\
\hline $\mathrm{T} 2, \mathrm{~T} 3$ & 5 & 4 & \\
\hline N stage & & & 0.61 \\
\hline NO & 8 & 5 & \\
\hline $\mathrm{N} 1, \mathrm{~N} 2$ & 2 & 3 & \\
\hline Distant metastasis & & & 0.44 \\
\hline M0 & 10 & 7 & \\
\hline M1 & 0 & 1 & \\
\hline Recurrence & & & 0.12 \\
\hline Negative & 9 & 4 & \\
\hline Positive & 1 & 4 & \\
\hline
\end{tabular}

FOM, floor of mouth.

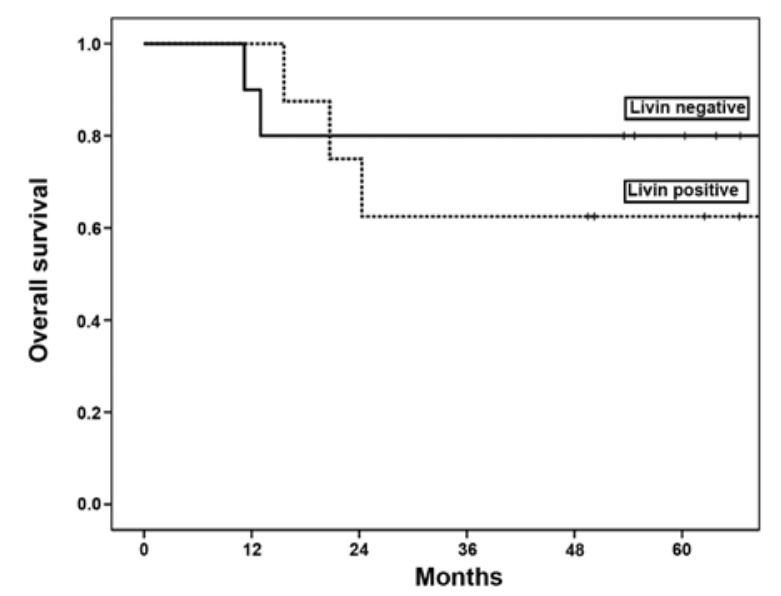

Figure 2. Kaplan-Meier survival curve showing the correlation of overall survival with positive expression (solid line) and negative expression (dotted line) of Livin in human oral squamous cell carcinoma (OSCC) $(\mathrm{p}=0.54)$.

the artificial wound gap became significantly narrower in the plates of the negative control siRNA-transfected PCI 50 cells 
A

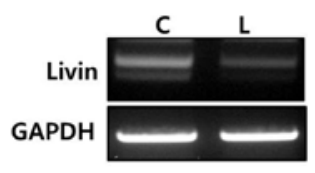

B

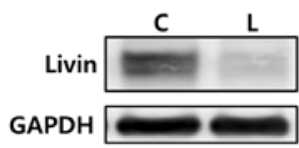

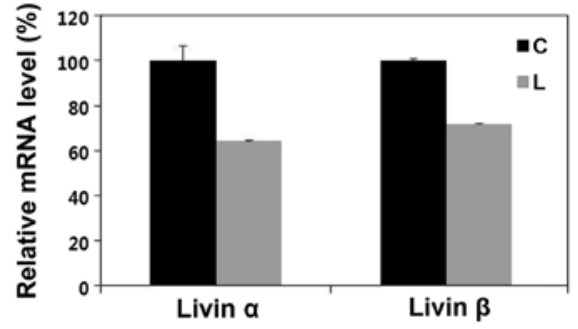

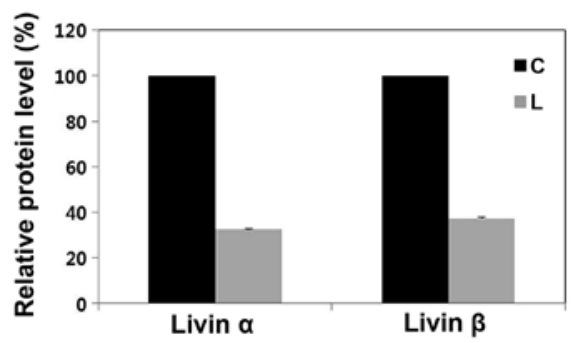

Figure 3. Livin knockdown by small-interfering RNA (siRNA) in the PCI 50 cell line. (A) The mRNA expression of Livin was decreased in the Livin small-interfering RNA (siRNA)-transfected PCI 50 cells (L) when compared with the negative control siRNA-transfected PCI 50 cells (C). (B) The protein expression of Livin was decreased by Livin knockdown in the PCI 50 cells. GAPDH was used as the loading control.
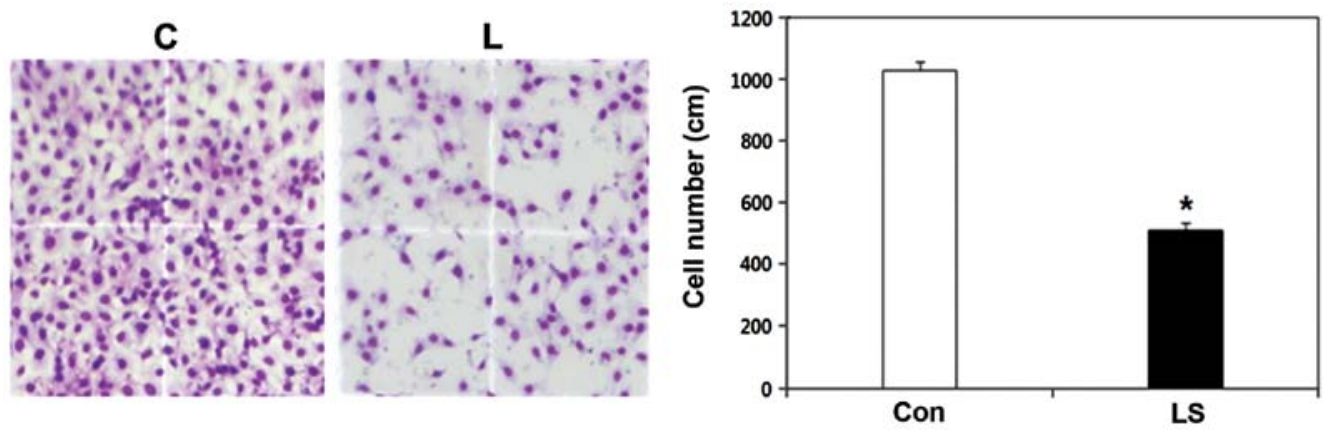

Figure 4. Effect of Livin knockdown on cell invasion in the PCI 50 cell line. The number of invading cells was significantly less in the Livin small-interfering RNA (siRNA)-transfected PCI 50 cells (L) when compared with the negative control siRNA-transfected PCI 50 cells (C). The stained invasive cells were counted and are represented as a bar graph between groups (mean $\pm \mathrm{SEM}, \mathrm{n}=3 ;{ }^{*} \mathrm{p}<0.01$ ).
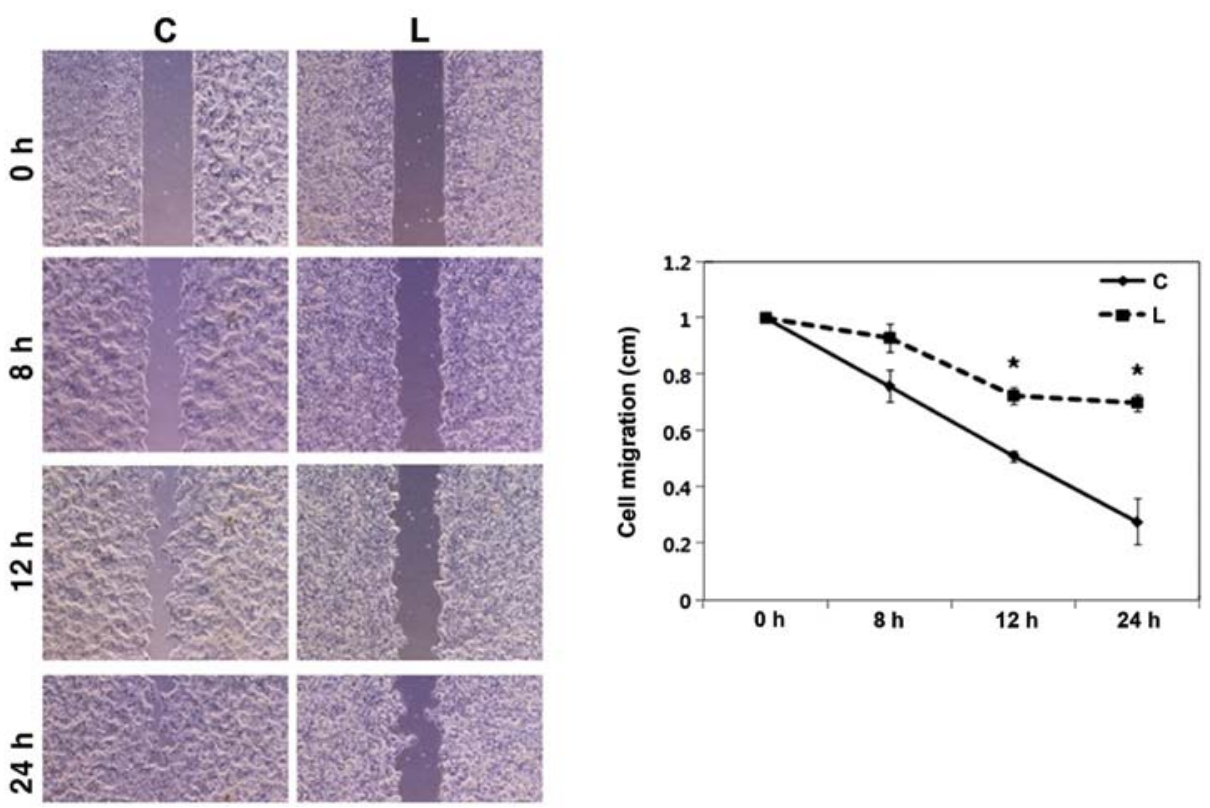

Figure 5. Effect of Livin knockdown on cell migration in the PCI 50 cell line. Cell migration was markedly decreased in the Livin small-interfering RNA (siRNA)-transfected PCI 50 cells (L) when compared with the negative control siRNA-transfected PCI 50 cells (C) at 12 and 24 h. Cell migration is displayed as relative healing distance measured in three random sites. Values indicate mean \pm SEM of three independent experiments $\left({ }^{*} \mathrm{p}<0.01\right)$. 


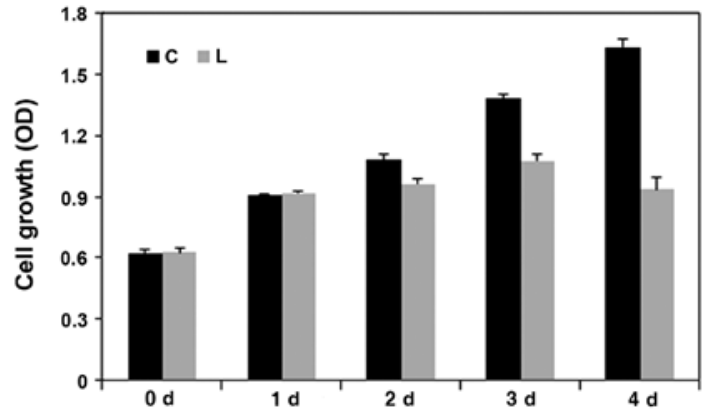

Figure 6. Effect of Livin knockdown on cell proliferation in the PCI 50 cell line. Proliferating cells was significantly decreased in the Livin smallinterfering RNA (siRNA)-transfected PCI 50 cells (L) when compared with the number in the negative control siRNA-transfected PCI 50 cells (C) at 2, 3 and 4 days $(\mathrm{p}=0.03, \mathrm{p}=0.01$ and $\mathrm{p}=0.003$, respectively).

when compared with that of the Livin siRNA-transfected PCI 50 cells at 12 and $24 \mathrm{~h}(\mathrm{p}<0.01)$ (Fig. 5). After $24 \mathrm{~h}$, the wound gaps were filled in the plates of the negative control siRNA-transfected OSCC cells. In contrast, the wound gaps were wide open in the plates of Livin siRNA-transfected OSCC cells after $24 \mathrm{~h}$. The results clearly showed that Livin knockdown resulted in significantly diminished cell migration in the human OSCC cells.

Knockdown of Livin results in significantly decreased cell proliferation in human OSCC cells. The cell viability was assessed at 1,2, 3 and 4 days in the negative control siRNAtransfected PCI 50 cells and Livin siRNA-transfected PCI 50 cells to assessed the effect of Livin on cell proliferation (Fig. 6). The number of proliferating cells was significantly decreased in the Livin siRNA-transfected PCI 50 cells when compared to this number in the negative control siRNA-transfected PCI 50 cells at 2,3 and 4 days $(\mathrm{p}=0.03, \mathrm{p}=0.01$, and $\mathrm{p}=0.003$, respectively). The results clearly showed that Livin knockdown resulted in significantly decreased cell proliferation in human OSCC cells.

Knockdown of Livin induces cell apoptosis in human OSCC cells. To determine the impact of Livin on cell apoptosis, responses of Livin siRNA-transfected OSCC cells and negative control siRNA-transfected OSCC cells were compared by an Annexin V apoptosis assay. Livin-knockdown OSCC cells displayed increased apoptosis, compared with the control cells (Fig. 7A). The proportions of early and late apoptotic PCI 50 cells induced by transfection of Livin siRNA (37.4 and 7.1\%, respectively) were greater than that induced following transfection with negative control siRNA (11.6 and $1.2 \%$, respectively) (Fig. 7A). Additionally, an increase in cleaved caspase-3, cleaved caspase-7 and cleaved PARP, which are key enzymes of apoptosis, was noted in the Livin-knockdown OSCC cells (Fig. 7B). These results suggest that Livin knockdown-induced apoptosis was associated with the modulation of apoptosis regulatory proteins such as caspase-3, caspase-7 and PARP.

\section{Discussion}

The IAP family consists of a group of intracellular proteins that are essential for the regulation of apoptosis $(19,34)$. The
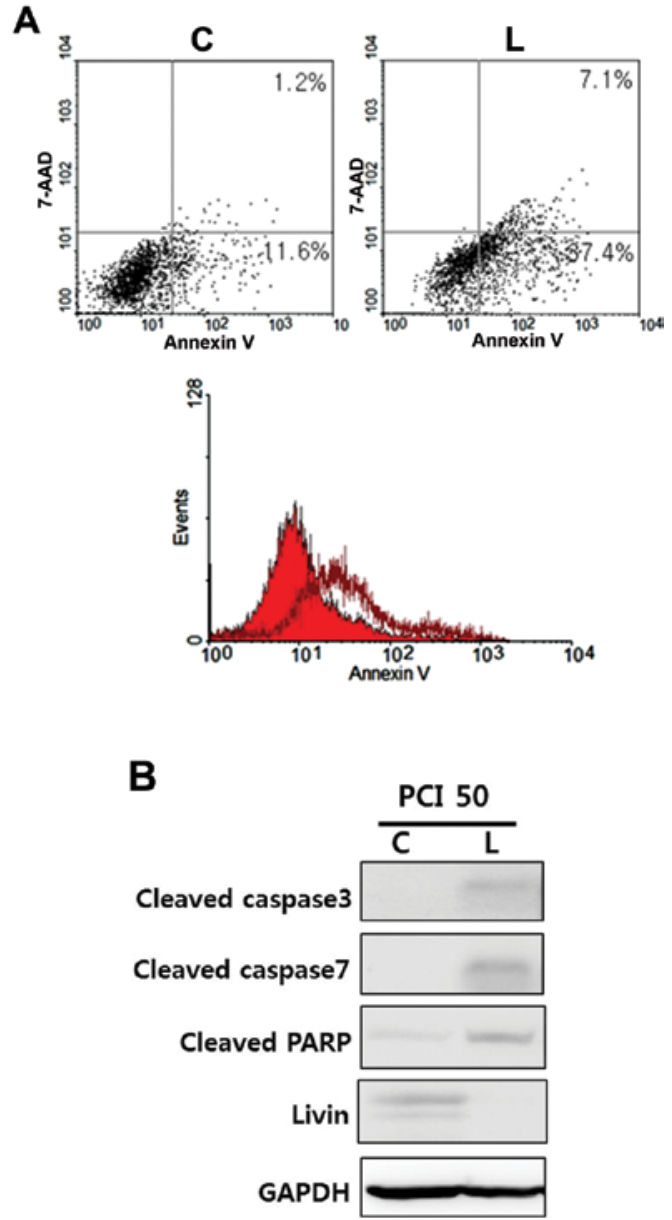

Figure 7. Effect of Livin knockdown on cell apoptosis in the PCI 50 cell line. (A) Livin-knockdown PCI 50 cells (L) displayed increased apoptosis, compared with the control cells (C). (B) The effects of Livin knockdown on the mediators of apoptosis in human OSCC cells. Livin knockdown induced activity of caspase-3, caspase-7, and poly-ADP ribose polymerase (PARP).

IAPs consist of one baculovirus IAP repeat (BIR) domain and a $\mathrm{COOH}$-terminal RING finger domain that suppresses apoptosis induced by a variety of stimuli (29). Apoptosis plays an important role in oncogenesis and tumor regression (35). Loss of apoptotic regulation can lead to a variety of diseases including cancer. IAPs bind directly and potentially inhibit a complex array of cysteine aspartyl-specific proteases, caspase-3, caspase-7, which are responsible for apoptosis and which are induced by diverse pro-apoptotic stimuli (34).

Livin is one of the potent members of the IAP family. Livin is undetectable in most normal tissues but is upregulated in a wide variety of human cancers (15-29). Livin expression contributes to tumor progression, a poor prognosis and is correlated with more aggressive tumor behavior, such as decreased response to radiotherapy and chemotherapy and reduced survival time in many human cancers $(18,22,23,36)$. These findings represents a potential novel therapeutic target for the treatment of human cancers.

However, whether Livin is related to head and neck cancer has not been investigated. Upon review of the English language literature, there is only one report of Livin expression in biopsy samples of nasopharyngeal carcinoma. Xiang et al reported that Livin was expressed in $48.75 \%$ of 
nasopharyngeal carcinoma cases (32). In the present study, Livin was expressed in 8 (44.4\%) of 18 OSCC tissues. This result is similar to that for nasopharyngeal carcinoma. In addition, OSCC tissues exhibited overexpression of Livin relative to the adjacent normal mucosa. This suggests that Livin may be involved in the development of OSCC. In addition, Livin is specifically overexpressed in cancer tissues, but almost absent in most normal adult tissues with the exception of the placenta $(37,38)$. This molecule represents a possible target for developing drugs that selectively eliminate cancer cells.

OSCC is characterized by a marked propensity for local invasion and lymphatic metastasis. Understanding the molecular mechanisms that mediate SCC invasion and metastasis may enable identification of novel therapeutic targets for management of tumor dissemination. Livin promotes the invasion, growth and apoptotic resistance in a variety of human cancer cells (14,39-41). In addition, Livin expression may be essential for survival of certain cancer cells $(17,21,23,41,42)$. In this study, Livin knockdown inhibited tumor cell invasion, migration and proliferation in OSCC cells. These results indicate participation of Livin in tumor progression and metastasis in OSCCs and support immunohistochemical data showing an association of Livin expression with cervical lymph node metastasis in human OSCC tissues. In addition, Livin expression was found to be significantly associated with cell proliferation in the human OSCC tissues.

Livin was previously found to inhibit apoptosis by binding to caspase-3, -7 and -9 , and its E3 ubiquitin-ligase activity promotes the degradation of IAP antagonist SMAC/DIABLO (second mitochondrial-derived activator of caspase/direct IAP binding protein with low pI) (14,39-41). In the present study, Livin knockdown induced cell apoptosis in human OSCC cells. As knockdown of Livin suppression could lead to apoptotic cell death in human OSCC cells, suppression of Livin should have a benefit in cancer treatment. These results suggest that knockdown of Livin could provide a potential therapeutic strategy to induce apoptosis in OSCC cells and to significantly improve antitumor responses.

To determine the mechanisms of cell apoptosis in Livin siRNA-transfected OSCC cells, the change in apoptosis-related proteins in Livin siRNA-transfected OSCC cell lysate was evaluated. This study showed that the expression of cleaved caspase-3, - 7 and PARP was upregulated in human OSCC cells after knockdown of Livin. Therefore, Livin inhibits apoptosis by suppressing the activity of caspases in human OSCC cells.

Finally, we assessed the expression of Livin and its prognostic relevance in a well-defined series of human OSCC tissues with complete clinicopathological data including survival. No significant correlation was found between Livin expression and various clinicopathological parameters including age, gender, tumor location, stage, $\mathrm{T}$ stage, $\mathrm{N}$ stage, distant metastasis, and recurrence. Furthermore, Livin expression was not correlated with survival. However, the 3 -year overall survival was $80 \%$ in the negative Livin group and $63 \%$ in the positive Livin group. Although there was no statistically significant differences between Livin expression and survival, Livin expression had a trend toward predicting a reduced survival rate. This result may reflect the relatively small sample size. In addition, the steps involved in OSCC development and progression are not dependent on Livin expression alone but may be regulated by many biological processes including invasion and metastasis. Further studies are required to clarify the impact of Livin on the biologic and prognostic significance in OSCC.

In summary, knockdown of Livin inhibited tumor cell invasion, migration and proliferation in human OSCC cells. Knockdown of Livin induced cell apoptosis in human OSCC cells. Livin inhibited apoptosis by suppressing the activity of caspases in human OSCC cells. Livin was not related with the clinicopathologic parameters of patients with OSCC. However, Livin expression was predictive of a poor 3-year overall survival rate.

In conclusion, Livin is associated with invasive and oncogenic phenotypes such as tumor cell invasion, tumor cell migration, tumor cell proliferation, and resistance to apoptosis in human OSCC cells.

\section{References}

1. Jemal A, Siegel R, Ward E, Hao Y, Xu J and Thun MJ: Cancer statistics, 2009. CA Cancer J Clin 59: 225-249, 2009.

2. Gourin CG and Podolsky RH: Racial disparities in patients with head and neck squamous cell carcinoma. Laryngoscope 116: 1093-1106, 2006.

3. Jemal A, Siegel R, Ward E, Hao Y, Xu J, Murray T and Thun MJ: Cancer statistics, 2008. CA Cancer J Clin 58: 71-96, 2008.

4. Adjuvant chemotherapy for advanced head and neck squamous carcinoma. Final report of the Head and Neck Contracts Program. Cancer 60: 301-311, 1987.

5. Shah JP and Lydiatt W: Treatment of cancer of the head and neck. CA Cancer J Clin 45: 352-368, 1995.

6. Lavertu P, Adelstein DJ, Saxton JP, Secic M, Eliachar I, Strome M, Larto MA and Wood BG: Aggressive concurrent chemoradiotherapy for squamous cell head and neck cancer: an 8-year single-institution experience. Arch Otolaryngol Head Neck Surg 125: 142-148, 1999.

7. Ambrosini G, Adida C and Altieri DC: A novel anti-apoptosis gene, survivin, expressed in cancer and lymphoma. Nat Med 3: 917-921, 1997.

8. Lin JH, Deng H, Huang Q and Morser J: KIAP, a novel member of the inhibitor of apoptosis protein family. Biochem Biophys Res Commun 279: 820-831, 2000.

9. Badran A, Yoshida A, Ishikawa K, Goi T, Yamaguchi A, Ueda T and Inuzuka M: Identification of a novel splice variant of the human anti-apoptosis gene survivin. Biochem Biophys Res Commun 314: 902-907, 2004.

10. Eckelman BP, Salvesen GS and Scott FL: Human inhibitor of apoptosis proteins: why XIAP is the black sheep of the family. EMBO Rep 7: 988-994, 2006.

11. Roy N, Deveraux QL, Takaahashi R, Salvesen GS and Reed JC: The c-IAP-1 and c-IAP-2 proteins are direct inhibitors of specific caspases. EMBO J 16: 6914-6925, 1997.

12. Vaux DL and Silke J: Mammalian mitochondrial IAP binding proteins. Biochem Bioph Res Commun 304: 499-504, 2003.

13. Wrzesień-Kuś A, Smolewski P, Sobczak-Pluta A, Wierzbowska A and Robak T: The inhibitor of apoptosis protein family and its antagonists in acute leukemias. Apoptosis 9: 705-715, 2004.

14. Yan B: Research progress on Livin protein: an inhibitor of apoptosis. Mol Cell Biochem 357: 39-45, 2011.

15. Lv J and Chen ZC: Resent research about Livin in cancer. Chin J Cancer Prev Treat 13: 1347-1350, 2006.

16. Ashhab Y, Alian A, Polliack A, Panet A and Ben Yehuda D: Two splicing variants of a new inhibitor of apoptosis gene with different biological properties and tissue distribution pattern. FEBS Lett 495: 56-60, 2001.

17. Yagihashi A, Ohmura T, Asanuma K, Kobayashi D, Tsuji N, Torigoe T, Sato N, Hirata K and Watanabe N: Detection of autoantibodies to survivin and livin in sera from patients with breast cancer. Clin Chim Acta 362: 125-130, 2005.

18. Hariu H, Hirohashi Y, Toriegoe T, Asanuma H, Hariu M, Tamura Y, Aketa K, Nabeta C, Nakanishi K, Kamiguchi K, Mano Y, Kitamura H, Kobayashi J, Tsukahara T, Shijubo N and Sato Nl: Aberrant expression and potency as a cancer immunotherapy target of inhibitor of apoptosis protein family, Livin/ ML-IAP in lung cancer. Clin Cancer Res 11: 1000-1009, 2005. 
19. Chung CY, Park YL, Kim N, Park HC, Park HB, Myung DS, Kim JS, Cho SB, Lee WS and Joo YE: Expression and prognostic significance of Livin in gastric cancer. Oncol Rep 30: 2520-2528, 2013.

20. Qiuping Z, Jei X, Youxin J, Wei J, Chun L, Jin W, Qun W, Yan L, Chungsong H, Mingzhen Y, Qingping G, Kejian Z, Qun L, Junyan L and Jinguan T: CC chemokine ligand 25 enhances resistance to apoptosis in $\mathrm{CD}^{+} \mathrm{T}$ cells from patients with T-cell lineage acute and chronic lymphocytic leukemia by means of livin activation. Cancer Res 64: 7579-7587, 2004.

21. Choi J, Hwang YK, Sung KW, Lee SH, Yoo KH, Jung HL, Koo HH, Kim HJ, Kang HJ, Shin HY and Ahn HS: Expression of Livin, an antiapoptotic protein, is an independent favorable prognostic factor in childhood acute lymphoblastic leukemia. Blood 109: 471-477, 2007.

22. Gazzaniga P, Gradilone A, Giuliani L, Gandini O, Silvestri I, Nofroni I, Saccani G, Frati L and Aglianò AM: Expression and prognostic significance of LIVIN, SURVIVIN and other apoptosis-related genes in the progression of superficial bladder cancer. Ann Oncol 14: 85-90, 2003

23. Kim DK, Alvarado CS, Abramowsky CR, Gu L, Zhou M, Soe MM, Sullivan K, George B, Schemankewitz E and Findly HW: Expression of inhibitor-of-apoptosis protein (IAP) livin by neuroblastoma cells: correlation with prognostic factors and outcome. Pediatr Dev Pathol 8: 621-629, 2005.

24. Gordon GJ, Mani M, Mukhopadhyay L, Dong L, Edenfield HR, Glickman JN, Yeap BY, Sugarbaker DJ and Bueno R: Expression patterns of inhibitor of apoptosis proteins in malignant pleural mesothelioma. J Pathol 211: 447-454, 2007.

25. Lopes RB, Gangeswaran R, McNeish IA, Wang Y and Lemoine NR: Expression of the IAP protein family is dysregulated in pancreatic cancer cells and is important for resistance to chemotherapy. Int J Cancer 120: 2344-2352, 2007.

26. Nedelcu T, Kubista B, Koller A, sutzbacher I, Mosberger I, Arrich F, Trieb K, Kotz R and Toma CD: Livin and Bcl-2 expression in high-grade osteosarcoma. J Cancer Res Clin Oncol 2: $237-244,2008$.

27. Crnković-Mertens I, Wagener N, Semzow J, Grőne EF, Haferkamp A, Hohenfellner M, Butz K and Hoppe-Seyler F: Targeted inhibition of Livin resensitizes renal cancer cells towards apoptosis. Cell Mol Life Sci 64: 1137-1144, 2007.

28. Kempkensteffen C, Hinz S, Christoph F, Krause H, Koellemann J, Magheli A, Schrader M, Schostak M, Miller K and Weikert S: Expression of the apoptosis inhibitor livin in renal cell carcinomas: correlations with pathology and outcome. Tumor Biol 28: 132-138, 2007.

29. Myung DS, Park YL, Chung CY, Park HC, Kim JS, Cho SB, Lee WS, Lee KH, Lee JH and Joo YE: Expression of Livin in colorectal cancer and its relationship to tumor cell behavior and prognosis. PLoS One 8: e73262, 2013.
30. Liu X, Chen N, Wang X, He Y, Chen X, Huang Y, Yin W and Zhou Q: Apoptosis and proliferation markers in diffusely infiltrating astrocytomas: profiling of 17 molecules. J Neuropathol Exp Neurol 65: 905-913, 2006.

31. Wang R, Lin F, Wang X, Gao P, Dong K, Zou AM, Cheng SY, Wei SH and Zhang HZ: Silencing Livin gene expression to inhibit proliferation and enhance chemosensitivity in tumor cells. Cancer Gene Ther 15: 402-412, 2008.

32. Xiang Y, Yao H, Wang S, Hong M, He J, Cao S, Min H, Song E and Guo X: Prognostic value of Survivin and Livin in nasopharyngeal carcinoma. Laryngoscope 116: 126-130, 2006.

33. Edge S, Byrd DR, Compton CC., Fritz AG, Greene FL and Trotti A (eds.): American Joint Committee on Cancer - Cancer Staging Manual. 7th edition. Springer, New York, pp649, 2010.

34. Kenneth NS and Duckett CS: IAP proteins; regulators of cell migration and development. Curr Opin Cell Biol 24: 871-875, 2012.

35. Green D and Kroemer G: The central executioners of apoptosis: caspases or mitochondrial. Trends Cell Bio 8: 267-271, 1998.

36. Xi RC, Biao WS and Gang ZZ: Significant elevation of survivin and livin expression in human colorectal cancer: inverse correlation between expression and overall survival. Onkologie 34: 428-432, 2011.

37. Kasof GM and Gomes BC: Livin, a novel inhibitor of apoptosis protein family member. J Biol Chem 276: 3238-46, 2001.

38. Sun JG, Liao RX, Zhang SX, Duan YZ, Zhuo WL, Wang XX, Wang ZX, Li DZ and Chen ZT: Role of inhibitor of apoptosis protein Livin in radiation response in nonsmall cell lung cancer. Cancer Biother Radiopharm 26: 585-592, 2011.

39. Wang L, Zhang Q, Liu B, Han M and Shan B: Challenge and promise: roles for Livin in progression and therapy of cancer. Mol Cancer Ther 7: 3661-3669, 2008.

40. Chang $\mathrm{H}$ and Schimmer AD: Livin/melanoma inhibitor of apoptosis protein as a potential therapeutic target for the treatment of malignancy. Mol Cancer Ther 6: 24-30, 2007.

41. Liu B, Han M, Wen JK and Wang L: Livin/ML-IAP as a new target for cancer treatment. Cancer Lett 250: 168-176, 2007.

42. Wagener N, Crnković-Mertens I, Vetter C Macher-Gőppinger S, Bedke J, Grőne EF, Zentgraf H, Pritsch M, Hoppe-Seyler K, Buse S, Haferkamp A, Autschbach F, Hohenfellner M and Hoppe-Seyler F: Expression of inhibitor of apoptosis protein Livin in renal cell carcinoma and non-tumorous adult kidney. $\mathrm{Br}$ J Cancer 97: 1271-1276, 2007. 